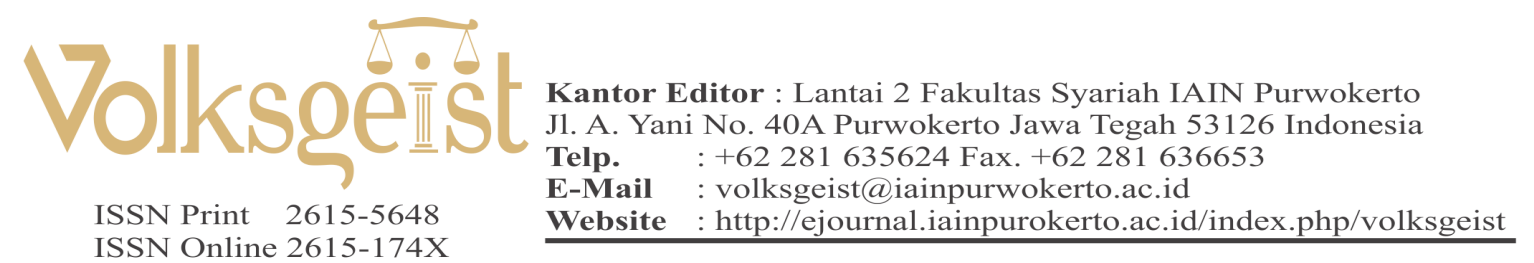

\title{
Dilema Hakim Pengadilan Agama dalam Menyelesaikan Perkara Hukum Keluarga Melalui Mediasi
}

\author{
Erie Hariyanto, ${ }^{1}$ Moh. Efendi, Sulistiyawati \\ Pascasarjana Institut Agama Islam Negeri Madura \\ 1Email: erie@iainmadura.ac.id
}

\begin{abstract}
Abstrak
Artikel ini bertujuan untuk mengetahui peran hakim dalam menyelesaikan perkara hukum keluarga melalui mediasi di Pengadilan Agama, dimana hakim sebagai memiliki kedudukan sebagai pejabat negara yang telah diatur dalam Undang-undang Nomor 43 Tahun 1999 tentang Pokokpokok Kepegawaian, juga dapat menjadi seorang mediator di peradilan sebagaimana diatur dalam Peraturan Mahkamah Agung yang Nomor 1 Tahun 2016 Tentang Prosedur Mediasi dimana hakim memiliki tanggungjawab untuk mengusahakan perdamaian dalam setiap tingkat persidangan dan jug terlibat dalam prosedur mediasi. Metode Penelitian yng dipakai dalam artikel ini menggunakan metode penelitian hukum normatif. Bahwasanya sampai saat ini hakim tetap memiliki peran yang sangat penting dalam menyelesaikan perkara hukum keluarga di Pengadilan Agama karena fakta ditemukan masih banyak proses perundingan dengan mediasi yang dibantu oleh hakim walaupun disatu sisi jumlah Mediator non hakim sudah tersedia walaupun di setiap daerah belum merata dari jumlah dan kapasitas mediator non-Hakim.
\end{abstract}

Kata Kunci: mediator hakim, mediator non hakim

\begin{abstract}
This article aims to determine the role of judges in resolving family law cases through mediation in the Religious Courts, where judges have the position as state officials as regulated in Law Number 43 of 1999 concerning Basic Personnel, can also be a mediator in the judiciary. as regulated in Supreme Court Regulation Number 1 of 2016 concerning Mediation Procedures where judges have the responsibility to seek peace at every level of the trial and are also involved in mediation procedures. The research method used in this article uses normative legal research methods. Whereas until now judges still have a very important role in resolving family law cases in the Religious Courts due to the fact that there are still many negotiating processes with mediation assisted by judges, even though on the one hand the number of non-judge mediators is available, although in each region it is not evenly distributed in terms of number and capacity. non-judge mediator.
\end{abstract}

Keywords: judge mediator, non judge mediator 


\section{Sejarah Artikel}

Dikirim: 18 Desember 2020

Direview: 15 Juni 2021

Diterima: 27 Juni 2021

Diterbitkan: 30 Juni 2021

\section{PENDAHULUAN}

Peradilan Agama merupakan suatu pilar kekuasaan kehakiman yang berperan penting dalam proses penegakan hukum. Adapun peran dari kelembagaan Peradilan Agama itu dituntut mampu untuk menyediakan ruang dalam penegakan hukum melalui proses mediasi. Mediasi merupakan suatu proses penyelesaian kasus atau sengketa hukum yang dilakukan baik di dalam maupun di luar pengadilan melalui peran pihak ketiga yang bertindak sebagai mediator. Dalam menjalankan tugasnya, seorang mediator umumnya menengahi dan menyelesaikan sengketa antara para pihak, di mana ia harus berada di tengah-tengah (posisi netral) dan tidak memihak salah satu pihak dalam menyelesaikan sengketa. Ia harus mampu menjaga kepentingan para pihak yang bersengketa secara adil dan sama sehingga mampu menumbuhkan kepercayaan dari para pihak yang bersengketa. ${ }^{1}$

Konsep perdamaian dalam Hukum Acara Perdata Indonesia telah tercantum dalam hukum acara perdata dalam pasal 130 H.IR/154 R.Bg. dimana hakim pada sidang pertama mempunyai kewajiban untuk mendamaikan para pihak yang bersengketa. Karena pasal tersebut tidak mampu mendorong para pihak untuk mengunakan jalan damai, maka MA mengeluarkan Surat Edaran (SEMA) No. $1 / 2002$ tentang pemberdayaan Pengadilan Pertama Menerapkan Lembaga Damai. Pada praktiknya SEMA tersebut belum mampu mengoptimalkan lembaga perdamaian sehingga disempurnakan den-

\footnotetext{
Suwanda Suwanda, "Peran Hakim dalam Penyelesaian Perkara Perdata Agama Melalui Mediasi Di Pengadilan," ADLIYA: Jurnal Hukum dan Kemanusiaan 9, no. 1 (2015): 2-3, https://doi.org/10.15575/adliya. v9i1.6156.
}

gan Peraturan Mahkamah Agung (PERMA) No. 2 /2003 tentang prosedur mediasi di Pengadilan. Praktik di lapangan menunjukkan bahwa PERMA tersebut memiliki beberapa kelemahan sehingga MA memutuskan untuk merevisi dengan PERMA No. 1/2008 untuk lebih mendayagunakan mediasi yang terkait dengan proses penyelesaian sengketa di pengadilan.

Praktik Mediasi telah terbukti mengurangi penumpukan perkara di pengadilan lebih khusus lagi Pengadilan Agama tentu akan memberi dampak positif pada lebih efektif dan efisiennya penyelesaian sengketa di Pengadilan Agama dalam waktu dan biaya yang dikeluarkan oleh para pihak. Pada tanggal 03 Februari 2016, MA memperbarui ketentuan PERMA No.1 Tahun 2008 dengan PERMA No.1 Tahun 2016 tentang Mediasi. Pertama, terkait batas waktu mediasi yang lebih singkat dari 40 hari menjadi 30 hari terhitung sejak penetapan perintah melakukan Mediasi. Kedua, adanya kewajiban bagi para pihak (inpersoon) untuk menghadiri secara langsung pertemuan Mediasi dengan atau tanpa didampingi oleh kuasa hukum, Ketiga, hal yang paling baru adalah adanya aturan tentang iktikad baik dalam proses mediasi dan akibat hukum para pihak yang tidak beriktikad baik dalam proses mediasi.

Proses penyelesaian sengketa melalui mediasi merupakan penyelesaian yang sangat menguntungkan para pihak. Sedangkan di Pengadilan sendiri yang notabanenya sebagai tempat penyelesaian perkara, maka mediasi ini selalu digunakan dalam penyelesaiannya dan yang menjadi penengah/mediator yaitu seorang hakim. Sebagaimana fungsi dan tugas seorang hakim yang berkedudukan sebagai pejabat negara yang telah diatur oleh Undang-Undang Nomor 8 Tahun 1974 sebagaimana yang telah dirubah oleh Undang-Undang Nomor 43 Tahun 1999 dengan adanya Pokok-Pokok Kepegawaian. Dapat kita ketahui bahwasanya 
seorang hakim memiliki tugas yang sangat penting yang terdapat dalam sistem kekuasaan kehakiman. Tentunya peran hakim sangat penting untuk mewujudkan keadilan dimana keadilan merupakan harapan yang besar setiap subyek hukum. Dalam proses penyelesaian perkara di Pengadilan, mediasi merupakan kunci pembuka perkara yang kemudian dilanjutkan dengan pemeriksaan pokok perkara, sebelum persidangan dilanjutkan ke pokok perkara Ketua Majelis wajib menetapkan mediator atas persetujuan para pihak untuk melakukan upaya damai kedua belah pihak yang berperkara. ${ }^{2}$

Terjadinya suatu persengketaan perdata maka cara penyelesaiannya dengan upaya perdamaian, hasil dari upaya penyelesaian dengan cara perdamaian merupakan upaya yang baik yang pada akhirnya para pihak bisa mencapai suatu solusi. Pelaksanaan perdamaian di persidangan perdata yakni melalui proses mediasi yaitu penyelesaian perkara dengan cara perundingan untuk memperoleh kesepakatan bersama antara pihak-pihak bersengketa yang dibantu oleh pihak menengah yaitu mediator. ${ }^{3}$ Mediator disini yakni seorang hakim atau bahkan orang lain yang mempunyai sertifikat mediator yang ahli dalam mengatasi suatu perselisihan dan mempunyai jaringan yang kuat, mediator sebagai pihak yang tidak boleh membantu salah satu pihak yang bersengketa. ${ }^{4}$

$2 \quad$ Ilyas Ilyas, Syahrizal Abbas, dan Iman Jauhari, "Efektivitas Peran Hakim Sebagai Mediator Dalam Penyelesaian Perkara Perdata di Mahkamah Syar'iyah Jantho," Syiah Kuala Law Journal 1, no. 1 (2017): 8486, https://doi.org/10.24815/sklj.v1i1.12241.

3 Karmawan Karmawan, "Diskursus Mediasi Dan Upaya Penyelesaiannya," Kordinat: Jurnal Komunikasi Antar Perguruan Tinggi Agama Islam 16, no. 1 (8 April 2017): 119, https://doi.org/10.15408/ kordinat.v16i1.6457.

4 Made Rai Diascitta Hardi Sentana, I. Wayan Wesna Astara, dan I. Nyoman Gede Sugiartha, "Peranan Hakim untuk Mendamaikan Para Pihak yang Bersengketa dalam Perkara Perdata di Pengadilan Negeri Denpasar," Jurnal Analogi Hukum 2, no. 2 (20 Juli 2020): 205-6, https://doi.org/10.22225/ah.2.2.1933.203-208.
Didalam Peraturan Mahkamah Agung telah disebutkan bahwa dalam menyelesaikan suatu perkara haruslah mengikuti suatu prosedur yang telah ditetapkan terutama hakim mediator sebagai penengah untuk mendamaikan para pihak, baik secara formil maupun materiil. Karena proses ini telah ditetapkan dalam Perundang-undangan maka tentu hakim sebagai mediator haruslah mengikuti aturan-aturan mediasi yang ditetapkan sehingga penyelesaiannya tidak menyimpang dan bisa mencapai suatu tujuan perkara.

Berdasarkan atas latar belakang yang diuraikan diatas, maka penilitian ini dilakukan untuk menganalisis peran hakim dalam menyelesaikan perkara perdata melaui mediasi di Pengadilan Agama.

Adapun penggunaan metode dalam artikel ini menggunakan metode penelitian hukum normatif yang didukung pengamatan prosedur mediasi di Pengadilan di Agama di Kabupaten Pamekasan. Sumber primer dari artikel ini menggunakan bahan pustaka berupa jurna, buku, disertasi yang membahas topik peran hakim dalam mediasi baik di Pengadilan Agama maupun Pengadilan Negeri. Pemaparan terhadap pokok Permasalahan dapat dilakukan dengan cara pendekatan melalui analisis faktafakta yang terjadi di lapangan. ${ }^{5}$

\section{PEMBAHASAN}

\section{Peran Hakim dalam Mendamaikan Para Pihak Dalam Perkara Hukum Keluarga}

Di Indonesia penyelesaian konflik rumah tangga diselesaikan melalui Badan Penasihatan, Pembinaan dan Pelestarian Perkawinan (BP4). Lembaga yang menjadi mitra Departemen Agama sejak tahun 1960 pada dasarnya adalah "lembaga mediasi" khusus sengketa rumah tangga. Meskipun demikian terdapat perbedaan

5 Soerjono Soekanto, Penelitian Hukum Normatif (Jakarta: Raja Grafindo Persada, 2003), 13. 
antara BP4 dan lembaga mediasi. Dalam proses penyelesaian sengketa BP4 lebih cenderung menasehati dan mendoktrin pasangan rumah tangga yang berkonflik. Peran penasehat di BP4 sangat dominan laksana "ustadz" atau kiai yang menasehati santrinya. Berbeda dengan mediasi, dimana mediator hanya sebagai fasilitator, tidak boleh menasehati, adil dan tidak memihak. Para pihak sebagai penentu untuk menyelesaikan masalahnya dan mencari solusinya. Persamaannya terletak pada upaya damai antara pihak-pihak yang bersengketa. Apa yang dilakukan masyarakat pada dasarnya adalah proses negosiasi dengan menggunakan teknik interest based bargaining, yang merupakan teknik negosiasi modern atau dikenal dengan istilah "mediasi” yang sekarang popular dan diterapkan di berbagai Negara. Hakim adalah seorang pejabat peradilan Negara yang diberikan wewenang oleh undang-undang untuk mengadili. Kekuasaan kehakiman meupakan kekuasaan negara yang merdeka, melaksanakan peradilan untuk menegakkan hukum dan keadilan berdasarkan Pancasila demi terciptanya Negara Hukum Republik Indonesia, sesuai dengan ketentuan Undangundang Dasar Negara Republik Indonesia Tahun 1945 dalam pasal 24. Adapun kewajiban yang harus dipenuhi oleh seorang hakim yaitu diwajibkan dapat memberikan suatu pengertian bahwa perdamaian adalah salah satu cara penyelesaian yang lebih bagus dan lebih bijaksana dari pada melalui putusan pengadilan, baik dari pandangan hukum dimasyarakat maupun dilihat pada segi waktu, biaya, dan tenaga yang diperlukan. ${ }^{6}$

Menurut ketentuan Peraturan Mahkamah Agung Nomor 1 Tahun 2016 pasal 3 ayat (3) Apabila Hakim Pemeriksa Perkara tidak menyarankan dilakukannya mediasi kepada para pihak sehingga para pihak akhirnya tidak

6 Sentana, Astara, dan Sugiartha, "Peranan Hakim untuk Mendamaikan Para Pihak yang Bersengketa dalam Perkara Perdata di Pengadilan Negeri Denpasar," 205. melaksanakan mediasi maka Hakim Pemeriksa Perkara tersebut dinyatakan melanggar Perundang-undangan mengenai mediasi di Pengadilan dan Mahkamah Agung dengan putusan sela akan memerintahkan Pengadilan Tingkat Pertama untuk melakukan proses mediasi. Waktu yang diberikan adalah 30 hari terhitung pada saat diperolehnya pemberitahuan putusan sela Pengadilan Tinggi atau Mahkamah Agung. Hasil mediasi dan berkas perkara disampaikan oleh Ketua Pengadilan Tingkat I ke Pengadilan Tinggi atau Mahkamah Agung yang kemudian akan diputus oleh Mahkamah Agung atau pengadilan Tinggi. ${ }^{7}$

Para pihak baik penggugat maupun tergugat akan dijelaskan tentang Prosedur Mediasi oleh Hakim Pemeriksa Perkara yang berisikan:

1. Pengertian dan Manfaat mediasi, hal ini bertujuan agar para pihak baik tergugat maupun penggugat sadar akan pentingnya perdamaian dan apa saja keuntungan yang didapatkan apabila baik pihak penggugat maupun tergugat mau menempuh jalur perdamaian atau mediasi.

2. Kewajiban agar para pihak menghadiri langsung proses mediasi, serta memberitahukan apa akibat apabila para pihak atau salah satu pihak tidak beriktikad baik dalam jalannya proses mediasi. Akibat dari para pihak yang tidak beriktikad baik pada saat proses mediasi berlangsung adalah membayar biaya mediasi baik itu pihak tergugat maupun penggugat.

3. Biaya karena menggunakan Mediator non hakim atau bukan pegawai pengadilan karena penggunaan mediator hakim atau pegawai pengadilan tidak dikenakan biaya.

4. Apabila para pihak setuju atau sepakat melakukan perjanjian atau mediasi di persidangan maka hasil dari mediasi di

7 "Peraturan Mahkamah Nomor 1 Tahun 2016 Tentang Prosedur Mediasi di Pengadilan," t.t. 
persidangan tersebut akan di kukuhkan dengan akta perdamaian dan kewajiban para pihak untuk menandatangani formulir penjelasan mediasi. ${ }^{8}$

Setelah memberikan pemaparan tentang kewajiban melaksanakan mediasi Hakim Pemeriksa Perkara mewajibkan para pihak untuk menempuh mediasi hari itu juga untuk memilih mediator dengan batas waktu selama dua (2) hari. Hakim yang bertindak sebagai mediator harus berada ditengah-tengah para pihak yang bersengketa ataupun didalamnya, tidak boleh terpengaruh dari kondisi internal maupun eksternal, Mediator tidak berperan sebagai hakim, ia bukan hakim yang memutuskan siapa yang benar dan salah, bukan juga bertindak sebagai penasehat hukum, tetapi berperan sebagai penolong.

Hakim pemeriksa perkara akan menangguhkan proses persidangan guna memberikan waktu untuk para pihak melakukan perdamaian. Jangka waktu untuk para pihak baik pihak tergugat maupu penggugat melakukan mediasi adalah 30 (tiga puluh) hari terhitung pada saat melakukan Mediasi oleh Hakim Pemeriksa Perkara. Apabila waktu yang diberikan tidak mencukupi maka akan diberikan jangka waktu tambahan yaitu paling lama 30 (tiga puluh) hari terhitung sejak jangka waktu Mediasi yang di perintahkan oleh Hakim Pemeriksa Perkara berakhir dan para pihak harus memohonkan permintaan tambahan waktu kepada Hakim Pemeriksa Perkara dengan menjelaskan alasan mengapa dibutuhkan perpanjangan waktu tersebut.

Mediator hakim ataupun pegawai pengadilan yang ditunjuk sebagai mediator dapat

8 Lebih lanjut Febry Andhika Putri, Indra Perdana, dan Emiel Salim Siregar, "Peranan Hakim sebagai Mediator dalam Proses Mediasi untuk Menangani Perkara Perceraian (Studi di Pengadilan Agama Kisaran Nomor: 1414/Pdt.g/2019/Pa.kis.)," JURNAL TECTUM 1, no. 2 (28 Mei 2020): 271, http://jurnal.una.ac.id/index. $\mathrm{php} / \mathrm{jt} /$ article/view/1281. menentukan waktu dilaksanakannya mediasi, setelah mendapatkan penetapan penunjukan mediator oleh Hakim Pemeriksa Perkara. Mediator Hakim ataupun pegawai pengadilan yang telah ditunjuk dapat menggunakan gedung Pengadilan dan tidak dikenakan biaya untuk itu kepada para pihak. Pemanggilan para pihak oleh mediator dimintai bantuan kepada juru sita atau juru sita pengganti. Mediasi yang berhasil mencapai kesepakatan antara para pihak dibantu oleh mediator, yang kemudian dirumuskan secara tertulis dalam Kesepakatan Perdamaian yang ditanda tangani oleh Para Pihak dan Mediator. Pada saat merumuskan Kesepakatan Perdamaian mediator hakim maupun pegawai pengadilan yang ditunjuk/ dipilih harus memastikan agar kesepakatan tersebut tidak bertentangan dengan hukum, ketertiban umum dan kesusilaan, serta tidak merugikan pihak ketiga. Para pihak yang diwakili oleh kuasa hukumnya harus memberikan pernyataan tertulis bahwa pihak tersebut telah setuju atas perjanjian yang telah dicapai. Mediator akan mengajukan Kesepakatan Perdamaian kepada Hakim Pemeriksa Perkara yang kemudian dikukuhkan dalam Akta Perdamaian. ${ }^{9}$

SetelahmenerimaKesepakatan Perdamaian yang syarat dan ketentuanya telah terpenuhi, Hakim Pemeriksa Perkara menetapkan waktu sidang untuk membacakan Akta Perdamaian. Dimana para pihak diwajibkan untuk mematuhi dan melaksanakan isi dari putusan perdamaian yang telah mereka sepakati yang telah dikukuhkan atau dikuatkan dalam Akta Perdamaian. Tetapi apabila mediasi gagal maka tugas mediator untuk melaporkannya secara tertulis kepada Hakim Pemeriksa Perkara.

Semua cara yang ditempuh atau diusahakan oleh Hakim tersebut diharapkan akan menumbuhkan pengertian, kesadaran dan keinginan pihak-pihak yang bersengketa un-

9 Putri, Perdana, dan Siregar, "Peranan Hakim sebagai Mediator dalam Proses Mediasi." 
tuk mengakhiri sengketa secara perdamaian, sekalipun mungkin hati mereka tertutup atau tidak ada niat untuk mengadakan perdamaian. Apabila dengan berbagai cara telah ditempuh oleh Hakim dalam usaha mendamaikan para pihak ternyata tidak ada hasilnya, maka untuk menghindari jangan sampai penyelesaian perkara berlarut-larut Hakim harus menghentikan usahanya untuk sementara waktu untuk mendamaikan para pihak. Usaha hakim dalam mengusahakan perdamaian tidak akan selalu berujung dengan keberhasilan apabila tidak adanya kesadaran dari para pihak bersengketa yang ingin menyelesaikan perkaranya secara damai, karena dapat atau tidaknya perdamaian itu tercapai tergantung pada kebijaksanaan Hakim dan kesadaran serta keinginan para pihak yang bersengketa.

\section{Mediasi dan Penegakan Hukum di Pengadil- an Agama}

Mediasi merupakan jalan tengah dimana peran mediasi sebagai pihak ketiga, namun bukanlah orang yang bisa memutuskan perkara melainkan hanya memberi solusi dan tidak berpihak kepada siapapun sifatnya netral. ${ }^{10}$ Berdasar mediator ini mampu dalam menjaga kepentingan para pihak yang bersengketa secara adil dan sama sehingga menumbuhkan kepercayaan dari para pihak yang bersengketa. ${ }^{11}$

Berdasarkan penjelasan mediasi dari segi kebahasaan di atas, tampaknya kata mediasi lebih menekankan pada keberadaan pihak ketiga yang menjembatani para pihak bersengketa untuk menyelesaikan perselisihan. Penjelasan ini sangat penting untuk

10 Lebih lanjut baca. Yayah Yarotul Salamah, "Urgensi Mediasi Dalam Perkara Perceraian Di Pengadilan Agama," AHKAM : Jurnal Ilmu Syariah 13, no. 1 (1 Februari 2013): 82-84, https://doi.org/10.15408/ ajis.v13i1.953.

11 Syahrizal Abbas, Mediasi dalam Perspektif Hukum Syari'ah, Hukum Adat, dan Hukum Nasional (Jakarta: Kencana Prenada Media Group, 2009), 2. membedakan penyelesaian sengketa dengan bentuk arbitrase, ${ }^{12}$ mediasi, ${ }^{13}$ kompromi, dan lain-lain. Dengan demikian, mediator berada pada posisi di teng- ah dan netral antara para pihak yang bersengketa dan mengupayakan menemukan sejumlah kesepakatan sehingga bisa mencapai hasil bersama yang memuaskan para pihak yang bersengketa.

Menurut Peraturan Mahkamah Agung Republik Indonesia Nomor 1 Tahun 2008 tentang Prosedur Mediasi di Pengadilan, yang disebut dengan mediator adalah pihak netral yang membantu para pihak dalam proses perundingan guna mencari berbagai kemungkin-an penyelesaian sengketa tanpa menggunakan cara memutus atau memaksakan sebuah penyelesaian. Dengan kata lain, mediator adalah pihak ketiga yang memiliki tugas untuk menengahi dan menyelesai-kan sengketa antara para pihak. ${ }^{14}$ Sehingga dapat dikatakan mediasi itu sifatnya netral artinya tidak memihak kepada siapapun. Adapun proses mediasi sendiri terbuka antar pihakpihak, adil, jujur, saling tukar pendapat untuk meraih kesepakatan bersama, namun mediator tidak memutuskan suatu perselisihan melainkan sebagai titik tengah untuk mencapai suatu solusi. Sehingga esensi dari mediasi merupakan pihak dalam pengambilan keputusan dalam menyelsaikan perkara. Kewenangan pengambilan keputusan sepenuhnya berada di tangan para pihak. keberadaan mediator sangat penting sebab dialah yang bisa membantu dan meng-upayakan proses pengambilan keputusan menjadi lebih baik sehingga menghasilkan win

12 R. M. Gatot P. Soemartono, "Mengenal Alternatif Penyelesaian Sengketa Dan Arbitrase," dalam Arbitrase Mediasi Dan Negosiasi ("Universitas Terbuka," 2014).

13 Riscilia Lomban, "Penyelesaian Sengketa Perdata Melalui Mediasi," LEX PRIVATUM 1, no. 4 (12 November 2013), https://ejournal.unsrat.ac.id/index.php/ lexprivatum/article/view/3067.

14 Lebih lanjut baca. Nurul Ma'rifah, "Mediasi Dalam Perkara Perceraian," SAINTIFIKA ISLAMICA: Jurnal Kajian Keislaman 2, no. 01 (16 Juni 2017): 82. 
win solutions yang dapat diterima oleh mereka yang bertikai. ${ }^{15}$

Berangkat dari beberapa definisi yang ada mediasi akan terlaksana baik bila memenuhi unsur-unsur dari mediasi itu sendiri. Nurmaningsih menyebutkan bahwa unsur yang harus terpenuhi dalam proses mediasi, yaitu: 1) Adanya proses penyelesaian sengketa itu sendiri ber-asaskan kesukarelaan yang dikela dengan proses mediasi. 2) Adanya mediator atas kesepakatan bersama (orang yang sengketa). 3) Adanya mediator yang berperan mencari jalan penyelesaian. 4) Mediator tidak memiliki hak mengambil keputusan selama berlangsungnya mediasi. 5) Mediasi harus memiliki tujuan mencapai kata sepakat dan diterima oleh pihakpihak yang bersengketa. ${ }^{16}$

\section{Peran dan fungsi Hakim sebagai mediator di dalam PERMA Nomor 1 Tahun 2016}

Peran dan fungsi hakim didalam PERMA Nomor 1 Tahun 2016 ialah untuk menyelesaikan suatu perbedaan pedapat mengenai perdata yang telah masuk di dalam pengadilan tingkat pertama. ${ }^{17}$ Sebelum adanya PERMA Nomor 1 Tahun 2016 terkait Peran dan fungsi hakim telah ada Undang-undang Nomor 48 Tahun 2009 tentang Kekuasaan Kehakiman, terdapat beberapa pasal yang berkaitan dengan hukum, sebagai berikut: Pertama, terdapat di pasal 2 yang berbunyi keadilan yang sangat di junjung tinggi sehingga untuk memutuskan perkara tidak memihak siapapun, pancasila ini yang selalu berdasarkan atas undang-undang. Kedua, pasal 3 dengan bisa menjaga kemandiriannya yang ada di dalam segala sesuatu mengenai

15 Herowati Poesoko, "Penemuan Hukum oleh Hakim dalam Penyelesaian Perkara Perdata," Jurnal Hukum Acara Perdata ADHAPER 1, no. 2 (2015).

16 Nurnaningsih Amriani, Mediasi Alternatif Penyelesaian Sengketa Perdata di Pengadilan (Jakarta: RajaGrafindo Persada, 2011), 61-62.

17 "Peraturan Mahkamah Nomor 1 Tahun 2016 Tentang Prosedur Mediasi di Pengadilan," t.t. perkara pengadilan. Ketiga, pasal 4 berbunyi kita harus seadil-adilnya mengadili seseorang tidak boleh membedakan orang atau suku lain dan bahkan ia selalu menolong para justiabelen yang akan mengalahkan semua masalah dan halangan untuk menjadikan kenyataan yang ada dan di dasarkan peradilan dalam.

Keempat, pasal 5 ayat 1, ketika sebagai mediator harus mengikuti, menggali dan memahami nilai-nilai hukum yang sudah ada dan dengan adanya rasa keadilan yang hidup di dalam masyarakat. Kelima, pasal 8 ayat 2 dengan adanya pertimbangkan berat atau entengnya pidana, maka hakim tersebut wajib mengamati keadaan yang baik dan dengan demikian perbuatan yang tidak baik maka akan dituntut didalam tersebut. Keenam, pasal 14 ayat 2 adanya seorang hakim harus menyertakan pertimbangan dan pendapatnya yang secara tertulis, bahkan setiap semua keputusan pengadilan dan setiap semua perbedaan harus wajib melihat. Ketujuh, pasal 17 ayat 3 seorang hakim harus menundakan diri dari persidangan apabila seseorang hakim tersebut mempunyai ikatan hubungan kekeluargaan dengan ketua hakim. $^{18}$

Adanya seorang mediator atau seorang hakim haruslah mampu menerapkan hukum yang positif dan mengabaikan yang negatif. Dengan proses mediasilah sengketa para pihak dapat terselesaikan dan dibantu pihak mediator untuk memperoleh kesepakatan bersama. Sehingga dalam hal mediator itu adalah orang yang ahli dan bisa memutuskan suatu sengketa dan mediator disini adalah orang yang memiliki banyak jaringan dan bisa mencarikan solusi perkara sesuai fakta yang nyata.

Dengan demikian tugas dari mediator hakim ini tidak lain yaitu menangani permasalahan sengketa dalam hukum keluarga, tugas mediator hakim yang akan menyelesaikan

18 "Undang-undang Republik Indonesia Nomor 48 Tahun 2009 tentang Kekuasaan Kehakiman,” t.t. 
permasalahan sengketa ini dan bahkan hakim memberikan kesempatan kepada para pihak untuk menyampaikan permasalahan yang sudah ada dan usulan perdamaian ini yang ada di tempat pengadilan agama ataupun pengadilan ditingkat pertama secara damai yang sudah ada di pasal 14 Perma No 1 tahun 2016 ataupun dengan tanpa memiliki sertifikat mediator. Dengan demikian hal tersebut yang akan menjadi menarik dari mediator hakim ataupun yang telah banyak disoroti dan bahkan yang dikritisi yaitu tugas lain yang ada di mediator hakim dengan kapasitasnya sebagai hakim yaitu akan memberikan penyelesaian dengan secara ajudikasi. Dengan demikian sejak dalam pengintegrasian perma $1 / 2016$ yang telah terjadi kondisi yang membuat hakim memiliki peranganda senagai pengadil dan juru damai bagi pihak-pihak.

Prinsip-prinsi yang telah di pegang oleh mediator baik mediator hakim dan non hakim harus sama yaitu yaitu: Pertama, Prinsip netralitas (impartiality) Mediator wajib memelihara ketidak berpihakan terhadap para pihak, Mediator dilarang mempengaruhi atau mengarahkan para pihak untuk menghasilkan klausa yang dapat memberikan keuntungan pribadi bagi mediator, Mediator harus berijtihad baik dan tidak mengorbankan kepentingan para pihak.

Kedua, prinsip penentuan diri sendiri (self determination) yaitu Mediator wajib menyelenggarakan proses mediasi sesuai dengan prinsip diri sendiri oleh para pihak, Mediator wajib menghormati hak para pihak antara lain untuk konsultasi dengan penasihat hukumnya atau para ahli, Mediator wajib menghindari penggunaan ancaman, tekanan atau intimidasi dan paksaan terhadap salah satu atau kedua belah pihakuntuk membuat suatu keputusan, Mediator wajib memberitahu para pihak pada pertemuan lengkap pertama bahwa segala bentuk penyelesaian atau keputusan yang diambil dalam proses mediasi memerlukan persetujuan para pihak.

Ketiga,prinsipkerahasiaan(confidentiality) Mediator wajb memelihara kerahasiaan segala sesuatu baik dalam bentuk perkataan, notulensi atau catatan maupun dokumen yang terungkap dalam proses mediasi kecuali untuk kasuskasus sengketa puplik.

Keempat, Prinsip Bebas dari konflik pribadi (free from conflik interest) Seseorang dilarang untuk menjadi mediator dalam sebuah kasus sengketa yang diketahui bahwa keterlibatannya merupakan konflik kepentingan. Kelima, prinsip dasar aturan (ground rules) yaitu mediator wajib menjelaskan kepada para pihak pada pertemuan lengkap pertama tentang pengertian dan prosedur mediasi.

Dengan adanya kode etik profesi yaitu acuan perilaku perseorangan yang telah menunjukkan arah terhadap suatu profesi dan bahkan sekaligus menjamin kualitas moral individu profesi yang ada di mata masyarakat. Di dalam konteks profesi tersebut, kode etik ini yang memiliki karakteristik antara lain yaitu: Pertama, dengan demikian produk etika merupakan terapan dikarenakan menghasilkan penerapan pemikiran yang etis bagi suatu profesi yang tertentu; Kedua, dengan adanya berubahan ataupun diubah seiringnya perkembangan di jaman yang adanya kemajuan bagi di ilmu pengetahuan dan teknologi tersebut. Yang terjadi dampak negatifnya yaitu yang sering kali menyebabkan penyalahgunaan yang menimbukan keresahan bagi masyarakat dan bahkan membingungkan bagi profesi itu sendiri; Ketiga dengan adanya ini tidak akan pernah berlaku efektif apabila keberadaanya cuman hanya membiarkan begitu saja yaitu pemerintahan ataupun instansi lainnya tidak akan pernah menjiwai oleh cita-cita dan nilainilai yang hidup di dalam kalangan itu sendiri; Keempat, yang sudah mendapatkan hasil dari 
pengaturan diri yang menyangkut di bagian dalam kalangan profesi itu sendiri. Bahkan ini bertujuan agar bisa mewujudkan nilai-nilai moral yang sudah dianggap paling mendasar, dengan penerapannya ini tidak akan bisa memaksa dari luar; Kelima, dengan adanya profesional ini kita bisa mempunyai motivasi yang kuat dan bahkan mempunyai komitmen seumur hidup yang lebih baik terhadap kariernya. Keenam, dengan adanya tujuan yang utama yang menjadi keberadaan ialah agar bisa mencegah terjadinya perilaku yang tidak baik terhadap di kalangan profesi itu sendiri.

Dengan adanya kode etik hakim ataupun kode kehormatan hakim, seseorang yang mengemban profesi ini yang akan dituntut agar memiliki sifat-sifat tertentu, dengan demikian salah satunya yang terpenting ialah yang mampu memutuskan berdasar hati yang nurani dan bahkan prilaku hakim ini yang sudah melandaskan kepada prinsip-pinsip ketuhanan yang maha esa. Dengan demikian yang telah dikatakan sebelumnya yang sudah ada di dalam Perma nomor 1 tahun 2016 yang telah membuat hakim berhadapan dengan dua kode etik tersebut. Bahkan dengan adanya kode etik ini yang menjadi sangat sulit ketika seseorang harus mematuhi ataupun mentaati dua kode etik tersebut. Apalagi dengan sifat dari kedua peranan ini yang sulit menempatkan diri sebagai hakim dan sebagai mediator walaupun dari kapabilitas dan profesionalitas tidak diragukan lagi, sehingga perlu didorong pendayagunaan mediator-mediator yang dilahirkan dari Asosiasi-Asosiasi Profesi yang sudah memiliki ijin unutk melakukan pelatihan calon mediator yang profesional.

\section{PENUTUP}

Hakim sebagai pejabat peradilan Negara diberi kewenangan oleh undang-undang untuk mengadili, selain itu seorang hakim juga bisa menjadi juru damai dalam prosedur mediasi sebagai mana ketentuan Peraturan Mahkamah Agung Nomor 1 Tahun 2016, peran ganda menjadi kelebihan sekaligus kelemahan, kelebihannya mediator hakim lebih paham dan berpengalaman akan tugas dan tanggung jawab dalam melakukan upaya damai bagi para pihak, karena sudah menjadi tugas pokok dan fungsi juga berada dalam satu tempat pengadilan, kelemahannya posisi sebagai pengadil dan juru damai memiliki kode etik yang berbeda yang tidak menutup kemungkinan adanya benturan dalam pelaksanaan sebagai hakim dan sebagai seorang meditor dimana proses mediasi sendiri terdapat prinsip terbuka antar pihak-pihak, adil, jujur, saling tukar pendapat untuk meraih kesepakatan bersama, seorang mediator tidak memutuskan suatu perselisihan melainkan sebagai titik tengah untuk mencapai suatu solusi. Sedangkan untuk Peran dan fungsi hakim dituntut bagaimana menyelesaikan dan memutus berdasarkan pertimbangan undangundang. sehingga kehadiran mediator Nonhakim dari organisasi Profesi yang tersertifikasi Mahkamah Agung perlu digalakkan untuk menutup kekurangan mediator-mediator di lembaga Peradilan sehingga Hakim bisa fokus menjalankan tugas sebagai hakim dan mediator non hakim bisa lebih profesional dalam menjalankan tugas dan tanggungjawab tugas sebagai mediator sesaui dengan kode etik masing-masing.

\section{DAFTAR PUSTAKA}

Abbas, Syahrizal. Mediasi dalam Perspektif Hukum Syari'ah, Hukum Adat, dan Hukum Nasional. Jakarta: Kencana Prenada Media Group, 2009.

Amriani, Nurnaningsih. Mediasi Alternatif Penyelesaian Sengketa Perdata di Pengadilan. Jakarta: RajaGrafindo Persada, 2011.

Ilyas, Ilyas, Syahrizal Abbas, dan Iman Jauhari. "Efektivitas Peran Hakim Sebagai 
Mediator Dalam Penyelesaian Perkara Perdata di Mahkamah Syar'iyah Jantho." Syiah Kuala Law Journal 1, no. 1 (2017): 83-100. https://doi.org/10.24815/sklj. v1i1.12241.

Karmawan, Karmawan. "Diskursus Mediasi Dan Upaya Penyelesaiannya." Kordinat: Jurnal Komunikasi Antar Perguruan Tinggi Agama Islam 16, no. 1 (8 April 2017): 107-26. https://doi.org/10.15408/ kordinat.v16i1.6457.

Lomban, Riscilia. "Penyelesaian Sengketa Perdata Melalui Mediasi." LEX PRIVATUM 1, no. 4 (12 November 2013). https://ejournal.unsrat.ac.id/index. $\mathrm{php} /$ lexprivatum/article/view/3067.

Ma'rifah, Nurul. "Mediasi Dalam Perkara Perceraian." SAINTIFIKA ISLAMICA: Jurnal Kajian Keislaman 2, no. 01 (16 Juni 2017): 77-86.

"Peraturan Mahkamah Nomor 1 Tahun 2016 Tentang Prosedur Mediasi di Pengadilan," t.t.

Poesoko, Herowati. "Penemuan Hukum oleh Hakim dalam Penyelesaian Perkara Perdata." Jurnal Hukum Acara Perdata ADHAPER 1, no. 2 (2015).

Putri, Febry Andhika, Indra Perdana, dan Emiel Salim Siregar. "Peranan Hakim sebagai Mediator dalam Proses Mediasi untuk Menangani Perkara Perceraian (Studi di Pengadilan Agama Kisaran Nomor: 1414/ Pdt.g/2019/Pa.kis.)." JURNAL TECTUM 1, no. 2 (28 Mei 2020). http://jurnal.una. ac.id/index.php/jt/article/view/1281.
Salamah, Yayah Yarotul. "Urgensi Mediasi Dalam Perkara Perceraian Di Pengadilan Agama." AHKAM : Jurnal Ilmu Syariah 13, no. 1 (1 Februari 2013). https://doi. org/10.15408/ajis.v13i1.953.

Sentana, Made Rai Diascitta Hardi, I. Wayan Wesna Astara, dan I. Nyoman Gede Sugiartha. "Peranan Hakim untuk Mendamaikan Para Pihak yang Bersengketa dalam Perkara Perdata di Pengadilan Negeri Denpasar." Jurnal Analogi Hukum 2, no. 2 (20 Juli 2020): 203-8. https://doi.org/10.22225/ ah.2.2.1933.203-208.

Soekanto, Soerjono. Penelitian Hukum Normatif. Jakarta: Raja Grafindo Persada, 2003.

Soemartono, R. M. Gatot P. "Mengenal Alternatif Penyelesaian Sengketa Dan Arbitrase." Dalam Arbitrase Mediasi Dan Negosiasi. "Universitas Terbuka," 2014.

Suwanda, Suwanda. "Peran Hakim dalam Penyelesaian Perkara Perdata Agama Melalui Mediasi Di Pengadilan.” ADLIYA: Jurnal Hukum dan Kemanusiaan 9, no. 1 (2015): 01-22. https://doi.org/10.15575/ adliya.v9i1.6156.

"Undang-undang Republik Indonesia Nomor 48 Tahun 2009 tentang Kekuasaan Kehakiman," t.t. 